\title{
Mobile Technology Adoption by Indian Consumers
}

\author{
Deepshikha Aggarwal
}

\begin{abstract}
Mobile technology has penetrated into all sectors of business and personal communication. The mobile devices are not limited to communication but play a vital role as an emerging model for business. The companies are utilizing the mobile services to sell goods and services to the consumers. Facilities like mwallets have made the mobile commerce more successful. The aim of this paper is to understand the behavior of consumers with respect to mobile shopping and study the factors influencing the consumers while choosing mobile shopping. The study has been conducted for the shoppers in India. The data is collected with the help of a questionnaire designed keeping in mind the perspective of Indian consumers. The data analysis has been done using various statistical tools and results have been derived on how the various factors influence the behavioral intention of users to adopt mobile shopping. The technology acceptance model (TAM) has been used in the study as it is a popular approach to understand the user acceptance of technology. We have used the traditional factors of perceived usefulness, perceived ease of use and behavioral intention to use mobile shopping. We have also identifies and used certain external factors which may influence the user intention to choose mobile shopping. These are perceived enjoyment, perceived quality of service, technical skills of the user and privacy \& security.
\end{abstract}

Index Terms: Mobile shopping, Technology Acceptance Model (TAM), Mobile consumer behavior, mobile shopping intention, Data analysis.

\section{INTRODUCTION}

The development in the field of information technology has led to the popularization of mobile devices. Mobile commerce has become one of the most popular trends on the internet [1]. Though mobile shopping has been around for a long time but the major developments in the area have happened with the usage of advanced mobile devices such as smartphones and tablets and the popularity of mobile applications [2]. Mobile technology has become an integral part of our daily lives right from communication to web browsing [3].

The trend of mobile shopping has become so popular that it has emerged to be an interesting area of research in recent times. Mobile commerce is the set of applications on the mobile devices that enable the users to search, compare and buy products and services online anywhere and anytime [4].

Revised Manuscript Received on July 22, 2019.

Deepshikha Aggarwal, Department of Information Technology Jagan Institute of Management Studies, Delhi, India deepshikha.aggarwal@jimsindia.org
Mobile commerce refers to the usage of mobile applications for buying of products and services [5]. The increasing number of mobile devices and widespread availability of network connectivity has led to the mobile revolution [6]. The consumers are dependent on their mobile devices for various day to day needs [7]. The services such as mwallets have further enhanced the usage of mobile commerce and it is going to increase further with time.

The mobile phones with internet connectivity have reached everywhere even in developing countries like India. Mobile shopping and mobile payments has become a common thing. Consumers are using their smartphones for shopping, payments and searching [8]. The consumers are using more mobile devices and lesser of fixed computers for their online shopping and this trend is going to continue in future as well [9].

With the focus of customers concentrating on mobile devices, the companies are constantly working to understand consumer preferences and formulating their marketing strategies accordingly [10]. The major factor to consider here is personalization of content on mobile applications and making the interfaces user friendly so that the consumers are able to use these applications easily [11] [12].

This paper explores the mobile shopping experience of Indian consumers to understand the relationship between consumer acceptance of mobile commerce and various factors leading to its adoption.

\section{MOTIVATION FOR STUDY}

Mobile commerce has become such an important aspect of business that companies have to work on all aspects such as privacy and security along with marketing and promotions [13]. It is important to gain trust of the consumers so that they are comfortable in sharing their personal information and shopping preferences with the mobile commerce providers [14]. It is very important to identify the factors that influence the users to accept the mobile commerce usage. This would enable the companies to formulate a proper business strategy for the overall consumer satisfaction [15]. The purpose of this paper is to identify the factors that influence the behavioral intention of users to accept mobile commerce. The study also suggests a theoretical model that demonstrates how these factors influence the adoption of mobile commerce.

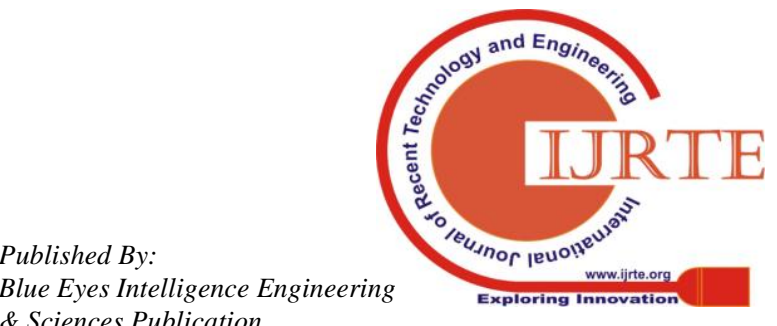




\section{THEORETICAL BACKGROUND}

The Technology Acceptance Model is a popular model among researchers to study the influence of various factors on the acceptance of a technology among the users. TAM indicates that the intention of users to accept and use a technology, also called the behavioral intention is determined by perceived ease of use and perceived usefulness [16]. A very useful feature of using TAM for the study is that it allows the researcher to incorporate various factors that influence the user acceptance for technology into the basic model [17]. TAM has been used extensively for predicting the acceptance of technology. In the current study, we have used the basic TAM variables of perceived ease of use, perceived usefulness and behavioral intention to use. Along with these, we have identified additional variables termed as external variables of privacy \& security, enjoyment, service quality and technical skills.

\section{HYPOTHESES DEVELOPMENT FOR APPLICATION OF TAM IN MOBILE COMMERCE}

A study is conducted using interviews and a questionnaire is developed to examine the factors affecting the user acceptance of m-shopping adoption. A conceptual model is developed (Figure 1) using the basic TAM variables and additional variables of privacy \& security, enjoyment, service quality and technical skills of users. The hypotheses are formulated on the basis of these variables.

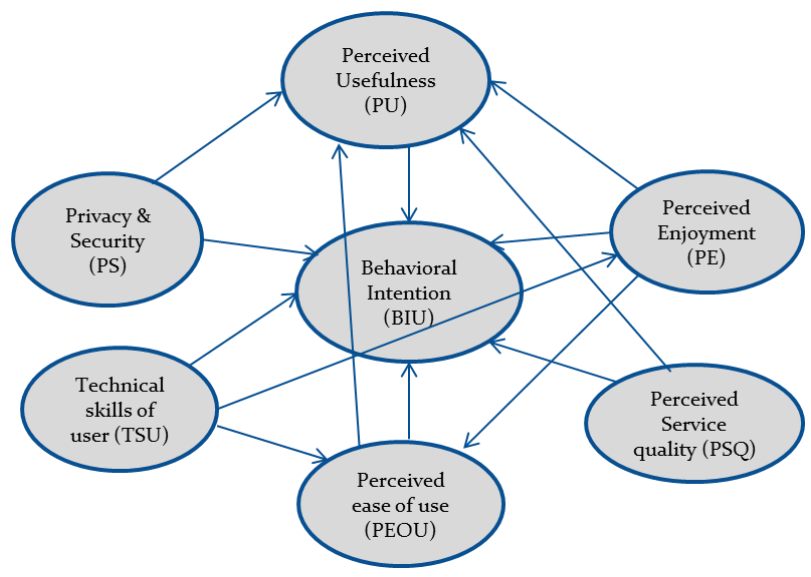

Fig 1: Model for Hypotheses

\section{A. Behavioral Intention}

TAM attempts to study the factors that influence the consumer's decision to accept a technology. Behavioral intention to use a technology is defined as the probability that the user is going to accept the usage of that technology. In this paper, behavioral intention indicates the probability that the consumers will purchase products and services through mobile applications. Other factors are mapped to behavioral intention to study their influence on user acceptance of technology.

\section{B. Perceived usefulness}

Perceived usefulness is the degree by which the user feels that using a technology will make his/her job easier [18]. In this study, perceived usefulness is how using mobile applications for the purchase of goods and services will make it easier for the user to search and shop. The users will accept a technology if they feel that using it would make their work easier. Thus a technology with high perceived usefulness will be accepted and therefore will have a positive effect on behavioral intention to use it. Based on this, the hypothesis is formed:

H1: Perceived Usefulness has a positive influence on behavioral intention for mobile shopping

\section{Perceived ease of use}

Perceived ease of use is the perceived comfort level of the users for using a technology [18]. If the users feel that they will be able to use the technology with ease, it will have a positive impact in the acceptance of technology. In this study, perceived ease of use indicates whether the consumers feel that they will be able to easily use mobile applications for shopping the consumers will accept a technology if they feel it would be easy for them to use it. Based on this, the following hypotheses are formed:

H2: Perceived ease of use has a positive influence on behavioral intention for mobile shopping.

H3: Perceived ease of use has a positive influence on Perceived usefulness of mobile shopping.

\section{Privacy \& security}

The users have to share their personal and financial information while making online transactions. The consumers do not want this information to be accessed by any unauthorized entity. Proper security measures have to be taken by online merchants to protect user information. The privacy and security of user information is a very important factor to influence the users to make online purchases. In this study we have taken this factor of privacy \& security to understand its impact on the user acceptance of mobile shopping. Based on this, the following hypothesis is formed:

H4: Privacy \& Security have a positive influence on behavioral intention for mobile shopping.

H5: Privacy \& Security have a positive influence on Perceived usefulness of mobile shopping.

\section{E. Perceived Enjoyment}


Shopping is not just purchasing goods and services but also acts as a means of fun and enjoyment for people. When we consider mobile shopping, it provides a personalized experience to the shoppers right at their fingertips. Therefore, for the consumers who get fun and pleasure while shopping, enjoyment will act as a motivating factor for acceptance of $\mathrm{m}$-shopping. Based on this the hypotheses are formed:

H6: Perceived Enjoyment has a positive influence on behavioral intention for mobile shopping.

H7: Perceived Enjoyment has a positive influence on Perceived usefulness of mobile shopping.

H8: Perceived Enjoyment has a positive influence on Perceived ease of use of mobile shopping.

\section{F. Perceived Service quality}

The quality of service that a merchant provides to its consumers motivates them to keep coming back. In this study about mobile shopping, service quality includes features like customer service, user interface, return \& exchange policies, etc. A good quality of service will play an important role in user acceptance of m-shopping. We will prove it with the help of following hypotheses:

H9: Perceived Service quality has a positive influence on behavioral intention for mobile shopping.

H10: Perceived Service quality has a positive influence on Perceived usefulness of mobile shopping.

\section{G. Technical skills of user}

People who possess good technical skills will obviously accept technology faster than the ones who lack the skills. People who lack technical skills generally would be resistant to accepting new technology. In case of mobile shopping, the technically skilled people may find it easier to shop through mobile applications. We will test it through the following hypotheses:

H11: Technical skills of user have a positive influence on behavioral intention for mobile shopping.

H12: Technical skills of user have a positive influence on enjoyment.

H13: Technical skills of user have a positive influence on Perceived ease of use of mobile shopping.

All the hypotheses are summarized in Table 1.

\begin{tabular}{|c|c|c|}
\hline & $\begin{array}{l}\text { behavioral intention for mobile } \\
\text { shopping }\end{array}$ & \\
\hline $\mathrm{H} 2$ & $\begin{array}{l}\text { Perceived ease of use has a } \\
\text { positive influence on } \\
\text { behavioral intention for mobile } \\
\text { shopping }\end{array}$ & PEOU->BIU \\
\hline $\mathrm{H} 3$ & $\begin{array}{l}\text { Perceived ease of use has a } \\
\text { positive influence on Perceived } \\
\text { usefulness of mobile shopping }\end{array}$ & PEOU->PU \\
\hline $\mathrm{H} 4$ & $\begin{array}{l}\text { Privacy \& } \begin{array}{l}\text { Security have a } \\
\text { influence onitive }\end{array} \\
\text { behavioral intention for mobile } \\
\text { shopping }\end{array}$ & PS->BIU \\
\hline H5 & $\begin{array}{l}\text { Privacy \& Security have a } \\
\text { positive influence on Perceived } \\
\text { usefulness of mobile shopping }\end{array}$ & PS->PU \\
\hline H6 & $\begin{array}{l}\text { Perceived Enjoyment has a } \\
\text { positive influence } \text { on } \\
\text { behavioral intention for mobile } \\
\text { shopping }\end{array}$ & PE->BIU \\
\hline $\mathrm{H} 7$ & $\begin{array}{l}\text { Perceived Enjoyment has a } \\
\text { positive influence on Perceived } \\
\text { usefulness of mobile shopping }\end{array}$ & PE->PU \\
\hline $\mathrm{H} 8$ & $\begin{array}{l}\text { Perceived Enjoyment has a } \\
\text { positive influence on Perceived } \\
\text { ease of use of mobile shopping }\end{array}$ & PE->PEOU \\
\hline H9 & $\begin{array}{l}\text { Perceived Service quality has a } \\
\text { positive influence on } \\
\text { behavioral intention for mobile } \\
\text { shopping }\end{array}$ & PSQ->BIU \\
\hline H10 & $\begin{array}{l}\text { Perceived Service quality has a } \\
\text { positive influence on Perceived } \\
\text { usefulness of mobile shopping }\end{array}$ & PSQ->PU \\
\hline H11 & $\begin{array}{l}\text { Technical skills of user have a } \\
\text { positive influence on } \\
\text { behavioral intention for mobile } \\
\text { shopping }\end{array}$ & TS->BIU \\
\hline $\mathrm{H} 12$ & $\begin{array}{l}\text { Technical skills of user have a } \\
\text { positive influence on enjoyment }\end{array}$ & TS->PE \\
\hline H13 & $\begin{array}{l}\text { Technical skills of user have a } \\
\text { positive influence on Perceived } \\
\text { ease of use of mobile shopping }\end{array}$ & TS->PEOU \\
\hline
\end{tabular}

\section{RESEARCH METHODOLOGY}

This section describes the research methodology used in this study.

The research is conducted by collecting primary data by means of a questionnaire. The questionnaire has been developed on the basis of factors explained in the previous section. Table 2 gives the detailed definitions of the study variables. The data collection details have been given along with the descriptive statistics and data analysis.

Table 1: Research Hypotheses

\begin{tabular}{|l|l|l|}
\hline Hypotheses & Description of Hypotheses & Path \\
\hline H1 & $\begin{array}{l}\text { Perceived Usefulness has a } \\
\text { positive influence on }\end{array}$ & PU->BIU \\
\hline
\end{tabular}


Table 2: Description of Study variables

\begin{tabular}{|c|c|c|}
\hline Factors & Questions & Description \\
\hline \multirow{3}{*}{$\begin{array}{l}\text { Perceived } \\
\text { Usefulness }\end{array}$} & PU1 & $\begin{array}{l}\text { Using the mobile apps for } \\
\text { shopping saves time }\end{array}$ \\
\hline & PU2 & $\begin{array}{l}\text { Using the mobile apps for } \\
\text { shopping is cheaper }\end{array}$ \\
\hline & PU3 & $\begin{array}{l}\text { Using the mobile apps for } \\
\text { shopping enhances my } \\
\text { shopping effectiveness }\end{array}$ \\
\hline \multirow{3}{*}{$\begin{array}{l}\text { Perceived } \\
\text { Ease of Use }\end{array}$} & PEOU1 & $\begin{array}{l}\text { Learning to use the mobile } \\
\text { apps for shopping is easy } \\
\text { for me }\end{array}$ \\
\hline & PEOU2 & $\begin{array}{l}\text { Searching products and } \\
\text { services of my choice is } \\
\text { easy with the mobile apps }\end{array}$ \\
\hline & PEOU3 & $\begin{array}{l}\text { I find it easier to shop using } \\
\text { the mobile apps }\end{array}$ \\
\hline \multirow{2}{*}{$\begin{array}{l}\text { Perceived } \\
\text { Enjoyment }\end{array}$} & PE1 & $\begin{array}{l}\text { Using mobile apps for } \\
\text { shopping is a pleasant } \\
\text { experience }\end{array}$ \\
\hline & PE2 & $\begin{array}{l}\text { I find using mobile apps for } \\
\text { shopping enjoyable }\end{array}$ \\
\hline \multirow{4}{*}{$\begin{array}{l}\text { Perceived } \\
\text { Quality of } \\
\text { Service }\end{array}$} & PSQ1 & $\begin{array}{l}\text { The completeness of } \\
\text { information about the } \\
\text { products will affect my } \\
\text { decision to use mobile apps } \\
\text { for shopping }\end{array}$ \\
\hline & PSQ2 & $\begin{array}{l}\text { The speed of delivery will } \\
\text { affect my decision to use } \\
\text { mobile apps for shopping }\end{array}$ \\
\hline & PSQ3 & $\begin{array}{l}\text { The ease of returning or } \\
\text { exchanging the products } \\
\text { will affect my decision to } \\
\text { use mobile apps for } \\
\text { shopping }\end{array}$ \\
\hline & PSQ4 & $\begin{array}{l}\text { The ease of payments will } \\
\text { affect my decision to use } \\
\text { mobile apps for shopping }\end{array}$ \\
\hline \multirow{3}{*}{$\begin{array}{l}\text { Behavioural } \\
\text { Intention to } \\
\text { Use }\end{array}$} & BIU1 & $\begin{array}{l}\text { I intend to continue using } \\
\text { mobile apps for shopping } \\
\text { in future }\end{array}$ \\
\hline & BIU2 & $\begin{array}{l}\text { I intend to shop through } \\
\text { mobile apps as much as } \\
\text { possible }\end{array}$ \\
\hline & BIU3 & $\begin{array}{l}\text { I recommend others to use } \\
\text { mobile apps for shopping }\end{array}$ \\
\hline \multirow{3}{*}{$\begin{array}{l}\text { Technical } \\
\text { Skills of the } \\
\text { User }\end{array}$} & TSU1 & $\begin{array}{l}\text { People having good } \\
\text { technical skills will have a } \\
\text { better shopping experience } \\
\text { on mobile apps }\end{array}$ \\
\hline & TSU2 & $\begin{array}{l}\text { People with good technical } \\
\text { skills will find it easy to } \\
\text { search products online }\end{array}$ \\
\hline & TSU3 & $\begin{array}{l}\text { People with good technical } \\
\text { skills will be able to keep } \\
\text { their data safer online }\end{array}$ \\
\hline $\begin{array}{l}\text { Privacy \& } \\
\text { Security }\end{array}$ & PS1 & $\begin{array}{l}\text { I feel that my personal } \\
\text { information is safe on } \\
\text { mobile shopping apps }\end{array}$ \\
\hline
\end{tabular}

\begin{tabular}{|l|l|l|}
\hline & PS2 & $\begin{array}{l}\text { I feel confident in making } \\
\text { payments through mobile } \\
\text { shopping apps }\end{array}$ \\
\hline
\end{tabular}

\section{A. Data Collection}

Data for the study has been collected using electronic questionnaire. The questionnaire was sent to 125 people out of whom 105 people responded. 3 questionnaires were rejected for being incomplete and therefore we analyzed 102 responses. The respondents were asked to fill the questionnaire which had 20 questions based on the factors of study and 3 questions for the gender, age group and email id. The factor based questions were based on 5 - point Likert scale ranging from 1 (Strongly Disagree) to 5 (Strongly Agree). The data demographics, shown in Table 3 indicates that $58.8 \%$ respondents were males and $31.4 \%$ females. The majority of participants, $58.8 \%$ are in the age group of 20 to 35 years.

Table 3: Data Demographics $(\mathrm{n}=102)$

\begin{tabular}{|c|c|c|c|}
\hline Demographics & & Frequency & Percent (\%) \\
\hline \multirow[t]{2}{*}{ Gender } & Male & 60 & 58.8 \\
\hline & Female & 42 & 41.2 \\
\hline \multirow[t]{3}{*}{ Age Group } & $\begin{array}{l}20-35 \\
\text { years }\end{array}$ & 60 & 58.8 \\
\hline & $\begin{array}{l}35 \text { to } 50 \\
\text { years }\end{array}$ & 32 & 31.4 \\
\hline & Above 50 & 10 & 9.8 \\
\hline
\end{tabular}

\section{B. Data Analysis}

The descriptive statistics for the collected data is shown in Table 4. The standard deviations range from 0.80 to 1.36 and the means are all above the midpoint 3. Skewness and kurtosis for all factors are less than 3 which indicate that there are no significant departures from normality. Hence the data collected is fit for analysis. The reliability of factors has been tested to ensure the consistency of results.

The reliability analysis measures the consistency and internal relationships among the constructs taken for each factor. This is done by using Cronbach's Alpha method as shown in Table 5.

Cronbach alpha values for all factors are above 0.7 which suggests that all the factors used in this study demonstrate acceptable internal consistency and will hence provide reliable results. 
Table 5: Cronbach's Alpha

\begin{tabular}{|l|l|}
\hline Factors & Cronbach's Alpha \\
\hline Perceived Usefulness & 0.65 \\
\hline Perceived Ease of Use & 0.7 \\
\hline Perceived Enjoyment & 0.75 \\
\hline Perceived Quality of Service & 0.84 \\
\hline Behavioural Intention to Use & 0.85 \\
\hline Technical Skills of the User & 0.93 \\
\hline Privacy \& Security & 0.71 \\
\hline
\end{tabular}

The data collected is tested for validity using the Kaiser-Meyer-Olkin (KMO) measure of sampling adequacy which is considered a good measure of factorability [19]. The KMO checks the validity of data y testing to see if the partial correlations within the data are close enough to zero to suggest that there is at least one latent factor underlying the selected variables. The minimum acceptable value is 0.50 . The KMO function in the psych package of $\mathrm{R}$ has been used in the study. It produces an overall Measure of Sampling Adequacy (MSA), for each item. The result is shown in Table 6 . The MSA for all factors is greater than 0.5 which indicates that all the factors are valid to be considered for the study.

Table 6: Factor Loadings

\begin{tabular}{|l|l|l|}
\hline \multicolumn{2}{|l|}{ Factors } & MSA \\
\hline Perceived & PU1 & 0.78 \\
\hline
\end{tabular}

Table 7: Correlation Matrix

\begin{tabular}{|c|c|c|}
\hline \multirow[t]{2}{*}{ Usefulness } & PU2 & 0.66 \\
\hline & PU3 & 0.6 \\
\hline \multirow{3}{*}{$\begin{array}{l}\text { Perceived Ease of } \\
\text { Use }\end{array}$} & PEOU1 & 0.89 \\
\hline & PEOU2 & 0.81 \\
\hline & PEOU3 & 0.74 \\
\hline \multirow{2}{*}{$\begin{array}{l}\text { Perceived } \\
\text { Enjoyment }\end{array}$} & PE1 & 0.87 \\
\hline & PE2 & 0.76 \\
\hline \multirow{4}{*}{$\begin{array}{l}\text { Perceived Quality } \\
\text { of Service }\end{array}$} & PSQ1 & 0.83 \\
\hline & PSQ2 & 0.65 \\
\hline & PSQ3 & 0.83 \\
\hline & PSQ4 & 0.69 \\
\hline \multirow{3}{*}{$\begin{array}{l}\text { Behavioural } \\
\text { Intention to Use }\end{array}$} & BIU1 & 0.7 \\
\hline & BIU2 & 0.81 \\
\hline & BIU3 & 0.83 \\
\hline \multirow{3}{*}{$\begin{array}{l}\text { Technical Skills of } \\
\text { the User }\end{array}$} & TSU1 & 0.77 \\
\hline & TSU2 & 0.75 \\
\hline & TSU3 & 0.61 \\
\hline \multirow{2}{*}{$\begin{array}{l}\text { Privacy } \quad \& \\
\text { Security }\end{array}$} & PS1 & 0.75 \\
\hline & PS2 & 0.84 \\
\hline
\end{tabular}

\section{HYPOTHESES TESTING \& RESULTS}

The hypotheses were tested by using $\mathrm{R}$ and MS excel. Correlation Analysis was performed on $\mathrm{R}$ and regression analysis was done using MS excel. The results for correlation analysis are shown in Table 7 and the results of regression analysis are shown in the results section according to hypotheses.

\begin{tabular}{|l|l|l|l|l|l|l|l|l|l|l|l|l|}
\hline & PU & PEOU & PE & PSQ & BIU & PSQTSU 0.53**** & $0.55 * * * *$ & $0.50 * * *$ & & \\
\hline PU & & & & & & BIU & $0.63 * * * *$ & $0.74 * * * *$ & $0.70^{* * * *}$ & $0.44 * *$ & \\
\hline PEOU & $0.67 * * * *$ & & & & & TS & $0.71 * * * *$ & 0.25 & $0.30^{*}$ & $0.76 * * *$ & $0.45 * * *$ & \\
\hline PE & $0.61 * * * *$ & $0.74 * * * *$ & & & & PS & 0.19 & $0.48 * * *$ & $0.36 *$ & 0.23 & $0.51 * * *$ & $0.44 * *$ \\
\hline
\end{tabular}

$\mathrm{p}<.0001$ "****", $\mathrm{p}<.001$ "***", $\mathrm{p}<.01$ "**", $\mathrm{p}<.05$ "*"

The correlation analysis as shown in Table 7 indicates a stron $\mathrm{g}$ correlation between PEOU and PU. The correlation is also clearly indicated between PE, PU \& PEOU. Correlation exist s between PSQ, PU, PEOU \& PE. Also there is a clear correl ation between BIU, PU, PEOU, PE \& PSQ. Correlation is th ere between TS, PU, PSQ \& BIU. It is also observed that cor relation does not exist between TS, PEOU \& PE. Also correl ation is observed between PS, PEOU, BIU \& TSU but no or very weak correlation exists between PS, PE \& PSQ. The res ults have been derived from Table 7 (Correlation Analysis) a nd Regression Analysis and have been summarized in this se ction according to the hypotheses.
H1 Perceived Usefulness has a positive influence on behavioral intention for mobile shopping

\begin{tabular}{|l|l|l|l|}
\hline Hypothesis & Path & Coefficient & $\begin{array}{l}\text { Standard } \\
\text { Error }\end{array}$ \\
\hline \multirow{3}{*}{ H1 } & PU->BIU & 0.740 & 0.134 \\
\cline { 2 - 4 } & $\boldsymbol{t}$ Stat & P-value & R Square \\
\cline { 2 - 4 } & 5.523 & $1.5 \mathrm{E}-06$ & 0.399 \\
\hline
\end{tabular}

The values of correlation coefficient, regression analysis and $\mathrm{p}<0.0001$ indicate that Perceived Usefulness impacts behavioral intention for mobile shopping. Hence hypothesis H1 is supported. 
H2 Perceived ease of use has a positive influence on behavioral intention for mobile shopping

\begin{tabular}{|l|l|l|l|}
\hline Hypothesis & Path & Coefficient & $\begin{array}{l}\text { Standard } \\
\text { Error }\end{array}$ \\
\hline \multirow{3}{*}{ H2 } & $\begin{array}{l}\text { PEOU-> } \\
\text { BIU }\end{array}$ & 0.830 & 0.113 \\
\cline { 2 - 4 } & $\boldsymbol{t}$ Stat & P-value & $\begin{array}{l}\boldsymbol{R} \\
\text { Square }\end{array}$ \\
\cline { 2 - 4 } & 7.364 & $2.6 \mathrm{E}-09$ & 0.541 \\
\hline
\end{tabular}

The values of correlation coefficient, regression analysis and $p<0.0001$ indicate that Perceived ease of use impacts behavioral intention for mobile shopping. Hence hypothesis $\mathrm{H} 2$ is supported.

H3 Perceived ease of use has a positive influence on Perceived usefulness of mobile shopping

\begin{tabular}{|l|l|l|l|}
\hline Hypothesis & Path & $\begin{array}{l}\text { Coeff } \\
\text { icient }\end{array}$ & $\begin{array}{l}\text { Standard } \\
\text { Error }\end{array}$ \\
\hline \multirow{4}{*}{ H3 } & $\begin{array}{l}\text { PEOU-> } \\
\text { PU }\end{array}$ & 0.643 & 0.106 \\
\cline { 2 - 4 } & $\boldsymbol{t}$ Stat & $\begin{array}{l}\text { P-val } \\
\text { ue }\end{array}$ & R Square \\
\cline { 2 - 4 } & 6.085 & $\begin{array}{l}2.2 \mathrm{E}- \\
07\end{array}$ & 0.446 \\
\hline
\end{tabular}

The values of correlation coefficient, regression analysis and $\mathrm{p}<0.0001$ indicate that Perceived ease of use impacts Perceived usefulness for mobile shopping. Hence hypothesis H3 is supported.

H4 Privacy \& Security have a positive influence on behavioral intention for mobile shopping

\begin{tabular}{|l|l|l|l|}
\hline Hypothesis & Path & Coefficient & $\begin{array}{l}\text { Standard } \\
\text { Error }\end{array}$ \\
\hline \multirow{3}{*}{ H4 } & PS->BIU & 0.466 & 0.117 \\
\cline { 2 - 4 } & $\boldsymbol{t}$ Stat & P-value & R Square \\
\cline { 2 - 4 } & 3.989 & $2.4 \mathrm{E}-04$ & 0.257 \\
\hline
\end{tabular}

The values of correlation coefficient, regression analysis and $\mathrm{p}<0.001$ indicate that Privacy \& Security impacts behavioral intention for mobile shopping. Hence hypothesis $\mathrm{H} 4$ is supported.

H5 Privacy \& Security have a positive influence on Perceived usefulness of mobile shopping

\begin{tabular}{|l|l|l|l|}
\hline Hypothesis & Path & Coefficient & $\begin{array}{l}\text { Standard } \\
\text { Error }\end{array}$ \\
\hline \multirow{3}{*}{ H5 } & PS->PU & 0.150 & 0.113 \\
\cline { 2 - 4 } & $\boldsymbol{t}$ Stat & P-value & R Square \\
\cline { 2 - 4 } & 1.322 & $1.9 \mathrm{E}-01$ & 0.037 \\
\hline
\end{tabular}

The values of correlation coefficient, regression analysis and p > 0.05 indicate that Privacy \& Security does not impact the Perceived usefulness for mobile shopping. Hence hypothesis H5 is not supported and rejected.

H6 Perceived Enjoyment has a positive influence on behavioral intention for mobile shopping

\begin{tabular}{|l|l|l|l|}
\hline Hypothesis & Path & Coefficient & $\begin{array}{l}\text { Standard } \\
\text { Error }\end{array}$ \\
\hline \multirow{3}{*}{ H6 } & PE->BIU & 0.812 & 0.122 \\
\cline { 2 - 4 } & $\boldsymbol{t}$ Stat & P-value & R Square \\
\cline { 2 - 4 } & 6.679 & $2.8 \mathrm{E}-08$ & 0.492 \\
\hline
\end{tabular}

The values of correlation coefficient, regression analysis and $\mathrm{p}<0.0001$ indicate that Perceived enjoyment impacts the behavioral intention for mobile shopping. Hence hypothesis H6 is supported.

H7 Perceived Enjoyment has a positive influence on Perceived usefulness of mobile shopping

\begin{tabular}{|l|l|l|l|}
\hline Hypothesis & Path & Coefficient & $\begin{array}{l}\text { Standard } \\
\text { Error }\end{array}$ \\
\hline \multirow{3}{*}{ H7 } & PE->PU & 0.601 & 0.116 \\
\cline { 2 - 4 } & $\boldsymbol{t}$ Stat & P-value & R Square \\
\cline { 2 - 4 } & 5.199 & $4.5 \mathrm{E}-06$ & 0.370 \\
\hline
\end{tabular}

The values of correlation coefficient, regression analysis and $\mathrm{p}<0.0001$ indicate that Perceived enjoyment impacts Perceived usefulness for mobile shopping. Hence hypothesis H7 is supported.

H8 Perceived Enjoyment has a positive influence on Perceived ease of use of mobile shopping

\begin{tabular}{|l|l|l|l|}
\hline Hypothesis & Path & Coefficient & $\begin{array}{l}\text { Standard } \\
\text { Error }\end{array}$ \\
\hline \multirow{3}{*}{ H8 } & $\begin{array}{l}\text { PE->PE } \\
\text { OU }\end{array}$ & 0.757 & 0.102 \\
\cline { 2 - 4 } & $\boldsymbol{t}$ Stat & P-value & R Square \\
\cline { 2 - 4 } & 7.417 & $2.2 \mathrm{E}-09$ & 0.545 \\
\hline
\end{tabular}

The values of correlation coefficient, regression analysis and $\mathrm{p}<0.0001$ indicate that Perceived enjoyment impacts Perceived ease of use for mobile shopping. Hence hypothesis H8 is supported.

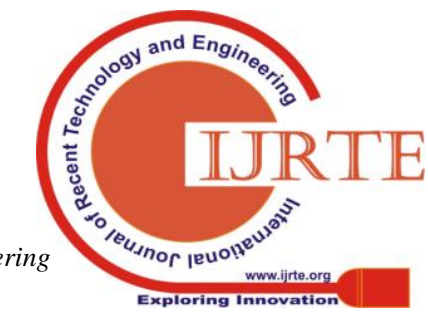


H9 Perceived Service quality has a positive influence on behavioral intention for mobile shopping

\begin{tabular}{|l|l|l|l|}
\hline Hypothesis & Path & Coefficient & $\begin{array}{l}\text { Standard } \\
\text { Error }\end{array}$ \\
\hline \multirow{3}{*}{ H9 } & $\begin{array}{l}\text { PSQ->BI } \\
\text { U }\end{array}$ & 0.517 & 0.155 \\
\cline { 2 - 4 } & $\boldsymbol{t}$ Stat & P-value & R Square \\
\cline { 2 - 4 } & 3.347 & $1.6 \mathrm{E}-03$ & 0.196 \\
\hline
\end{tabular}

The values of correlation coefficient, regression analysis and $\mathrm{p}<0.01$ indicate that Perceived service quality impacts behavioral intention for mobile shopping. Hence hypothesis H9 is supported.

H10 Perceived Service quality has a positive influence on Perceived usefulness of mobile shopping

\begin{tabular}{|l|l|l|l|}
\hline Hypothesis & Path & Coefficient & $\begin{array}{l}\text { Standard } \\
\text { Error }\end{array}$ \\
\hline \multirow{3}{*}{ H10 } & $\begin{array}{l}\text { PSQ->P } \\
\text { U }\end{array}$ & 0.532 & 0.124 \\
\cline { 2 - 4 } & $\boldsymbol{t}$ Stat & P-value & R Square \\
\cline { 2 - 4 } & 4.277 & $9.5 \mathrm{E}-05$ & 0.284 \\
\hline
\end{tabular}

The values of correlation coefficient, regression analysis and $\mathrm{p}<0.0001$ indicate that Perceived service quality impacts Perceived usefulness for mobile shopping. Hence hypothesis H10 is supported.

H11 Technical skills of user have a positive influence on behavioral intention for mobile shopping

\begin{tabular}{|l|l|l|l|}
\hline Hypothesis & Path & Coefficient & $\begin{array}{l}\text { Standard } \\
\text { Error }\end{array}$ \\
\hline \multirow{3}{*}{ H11 } & TS->BIU & 0.327 & 0.096 \\
\cline { 2 - 4 } & $\boldsymbol{t}$ Stat & P-value & R Square \\
\cline { 2 - 4 } & 3.420 & $1.3 \mathrm{E}-03$ & 0.203 \\
\hline
\end{tabular}

The values of correlation coefficient, regression analysis and $\mathrm{p}<0.001$ indicate that technical skills of user impact behavioral intention for mobile shopping. Hence hypothesis H11 is supported.

H12 Technical skills of user have a positive influence on enjoyment

\begin{tabular}{|l|l|l|l|}
\hline Hypothesis & Path & Coefficient & $\begin{array}{l}\text { Standard } \\
\text { Error }\end{array}$ \\
\hline \multirow{3}{*}{ H12 } & TS->PE & 0.188 & 0.088 \\
\cline { 2 - 4 } & $\boldsymbol{t}$ Stat & P-value & R Square \\
\cline { 2 - 4 } & 2.135 & $3.8 \mathrm{E}-02$ & 0.090 \\
\hline
\end{tabular}

The values of correlation coefficient, regression analysis and $p<0.05$ indicate that technical skills of the user impact perceived enjoyment for mobile shopping, though the correlation is not very strong. Hence hypothesis H12 is supported.

H13 Technical skills of user have a positive influence on Perceived ease of use of mobile shopping

\begin{tabular}{|l|l|l|l|}
\hline Hypothesis & Path & Coefficient & $\begin{array}{l}\text { Standard } \\
\text { Error }\end{array}$ \\
\hline \multirow{3}{*}{ H13 } & TS->PEOU & 0.161 & 0.092 \\
\cline { 2 - 4 } & $\boldsymbol{t}$ Stat & P-value & R Square \\
\cline { 2 - 4 } & 1.758 & $8.5 \mathrm{E}-02$ & 0.063 \\
\hline
\end{tabular}

The values of correlation coefficient, regression analysis and p > 0.05 indicate that technical skills of the user do not impact perceived ease of use for mobile shopping. Hence hypothesis $\mathrm{H} 13$ is not supported and rejected.

\section{DISCUSSION AND CONCLUSION}

Mobile phones have become an integral part of our lives and to utilize these devices to promote mobile commerce, marketers are taking advantage of this opportunity by bringing the shopping facility right at the fingertips of the users. The smartphones have penetrated all parts of India with service providers competing with each other to give cheapest rates of mobile data. The usage of mobile devices with internet facility has become affordable in India. The companies are continuously working towards making mobile commerce successful by accommodating mobile friendly marketing strategies. Companies are attracting customers towards mobile shopping by providing personalized search facilities and product recommendations, offering reward programs and discounts. The current study is conducted to examine the perceived usefulness and behavioral intention to use mobile shopping, the perceived ease of use for mobile devices, customer enjoyment in mobile shopping, the service quality of mobile apps, technical skills of mobile users and privacy and security concerns while using mobile devices. The study has been conducted on Indian consumers who are using mobile devices for shopping.

The findings of the study show the relationship between different factors affecting the users while choosing mobile shopping. The results of the study have been derived from the TAM with additional factors of perceived enjoyment, privacy $\&$ security, technical skills of the user and perceived service quality of mobile shopping applications. These factors have a significant effect on users' behavioral intention to use mobile shopping in addition to the traditional factors of TAM. The results of the study show that perceived usefulness, perceived ease of use, perceived service quality, privacy \& security of mobile applications, perceived enjoyment and technical skills of the user have a positive influence on the behavioral 
intention to use mobile applications for shopping. Hence these hypotheses were accepted. Though privacy \& security affects the intention to use but it does not influence the perceived usefulness of mobile applications for shopping. Hence this hypothesis was rejected. The technical skills of the user have a positive impact on the intention to use and perceived enjoyment but do not affect the perceived ease of use. Hence this hypothesis was also rejected. The results of the study can be useful for the companies providing the mobile shopping facility as the study clearly indicates the importance of the role of perceived enjoyment and perceived service quality on the user intention to use mobile shopping. The companies need to plan their marketing strategies to accommodate these factors and make the mobile shopping user friendly and provide pleasant shopping experience for the users. Also privacy \& security is important in affecting the user decision for mobile shopping. The study can be a motivating tool for the mobile commerce companies to focus on building positive customer relationship and work towards customer satisfaction by focusing on the factors described in the study.

\section{REFERENCES}

[1] N. Aharony, "Librarians' attitudes towards mobile services," 2013.

[2] Deloitte, "Global mobile consumer survey 2016: Trends from around the world," 2016.

[3] R. J.-h. Wang, "How mobile shopping affects customer purchase behavior," Journal of Retailing, 2015.

[4] K. H. Y. K. Yang, "Mobile Shopping Motivation: An Application of Multiple Discriminant Analysis," International Journal of Retail and Distribution Management, p. 778-789, 2012.

[5] B. Tariq, "Exploring factors influencing the adoption of mobile commerce," Journal of Internet Banking and Commerce, 2007.

[6] F. V. C. H. Davis, "Adoption and use of internet technologies and e-business solutions by Canadian micro-enterprises," in Annual Conference of the International Association for Management of Technology, Vienna, 2005.

[7] A. B. J. R. A. Holmes, "Mobile shopping behaviour: Insights into attitudes, shopping process involvement and location," International Journal of Retail \& Distribution Management, pp. 25-39, 2014.

[8] S. N. B. R. W. M. H. Fagan, "An empirical investigation into the relationship between computer self-efficacy, anxiety, experience, support and usage," Journal of Computer Information Systems, pp. 95-104, 2003.

[9] K. Yang, "Determinants of US Consumer Mobile Shopping Services," Journal, p. 262-270, 2010

[10] G. M. A. C. K. O. S. A. T. Wei, "What drives Malaysian m-commerce adoption? An empirical analysis," Industrial Management \& Data Systems, pp. 370-388, 2009.

[11] M. K. L. A. P. Brinker, "The Dawn of Mobile Influence - Discovering the Value of Mobile in Retail," Deloitte Digital, 2014.

[12] V. A. V. C. H. P. N. Shankar, "Mobile Marketing in the Retailing Environment: Current Insights," Journal of Interactive Marketing, 2010.

[13] R. B. P. W. F. Davis, "Extrinsic and intrinsic motivation to use computers in the workplace," Journal of Applied Social Psychology, pp. 1111- 1132, 1992.

[14] A. M. T. Z. M. V. Vaggelis Saprikis, "Mobile Shopping Consumers' Behavior: An Exploratory Study and Review," Journal of theoretical and applied electronic commerce research, 2018.

[15] V. J. Y. T. X. X. Venkatesh, "Consumer Acceptance and Use of Information Technology: Extending the Unified Theory of Acceptance and Use of Technology," MIS Quarterly, p. 156-178, 2012.

[16] V. Y. H. Eraay Celik, "Extending the Technology Acceptance Model for adoption of E-Shopping by Consumers in Turkey," Journal of Electronic Commerce Research, 2011.

[17] W. Al-Ghaith, "Applying The Technology Acceptance Model To Understand Social Networking Sites (Sns) Usage: Impact Of Perceived
Social Capital," International Journal of Computer Science \& Information Technology (IJCSIT), 2015.

[18] D. Davis, "Perceived usefulness, perceived ease of use and user acceptance of information technology," MIS Quarterly, pp. 319-340, 1989.

[19] Stephanie, 11 May 2016. [Online]. Available: https://www.statisticshowto.datasciencecentral.com/kaiser-meyer-olkin I.

\section{AUTHORS PROFILE}

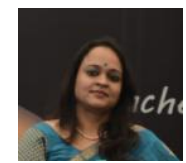

Dr Deepshikha Aggarwal is a highly accomplished faculty and researcher with extensive experience of over 18 years in academia. She has done B.E., M. Tech and $\mathrm{PhD}$ in Computer Science. She has written several research papers for various National and International journals and presented papers at different seminars and conferences. Her research interests include Social Network Analysis, Data quality, Computer networks, cyber security, E-learning and Data Science. 